\title{
Doing Well by Doing Good? Green Office Buildings
}

\author{
By PiEt EichHoltz, NiLs KoK AND John M. QuigLeY*
}

This paper provides the first credible evidence on the economic value of "green buildings" - derived from impersonal market transactions rather than engineering estimates. We analyze of clusters of certified green and nearby buildings, establishing that "rated" buildings command substantially higher rents and selling prices than otherwise identical buildings.

Variations in premiums are systematically related to energy-saving characteristics. Increased energy efficiency is associated with increased selling prices - beyond the premiums paid for a labeled building. Evidence suggests that the intangible effects of the label itself may also play a role in determining the values of green buildings in the marketplace. (JEL G51, M14, D92)

The behavior of the building and real estate sectors are quite important in matters of environmental sustainability. It is reported, for example, that buildings account for approximately forty percent of the consumption of raw materials and energy. In addition, 55 percent of the wood that is not used for fuel is consumed in construction. Overall, buildings and their associated construction activity account for at least 30 percent of world greenhouse gas emissions (Royal Institute of Chartered Surveyors, RICS, 2005).

\footnotetext{
* Eichholtz: Maastricht University, 6200 MD Maastricht, Netherlands (e-mail: p.eichholtz@maastrichtuniversity.nl); Kok: Maastricht University, 6200 MD Maastricht, Netherlands (email: n.kok@maastrichtuniversity.nl); Quigley: University of California, Berkeley, CA 94720-3880, USA (e-mail: quigley@econ.berkeley.edu). Financial support for this research was provided by the Mistra Foundation, Sweden, by the University of California Energy Institute, and by the Royal Institute of Chartered Surveyors (RICS). We are grateful for the encouragement of Stephen Brown of RICS. We especially acknowledge the help of Alexandra Sullivan of the U.S. Environmental Protection Agency (EPA) in assembling, interpreting and verifying the EPA data used in this analysis. We are grateful for the comments of Anthony Guma, Joseph Gyourko, Matthew Kahn, Alexandra Sullivan, Matthew Turner, Catherine Wolfram, and an anonymous reviewer. Naturally, all opinions and conclusions are our own.
} 
The impact of energy costs directly affects tenants and building owners. Energy represents 30 percent of operating expenses in a typical office building; this is the single largest and most manageable operating expense in the provision of office space.

Thus the design and operation of real estate can play an important role in energy conservation in advanced societies. Awareness of this fact is growing. The increasing emphasis on "green rating" systems for buildings - initiated by both government and industry - gives witness to this development. In general, these ratings assess the energy footprint of buildings, and they may provide owners and occupants with a solid yardstick for measuring the energy efficiency and sustainability of properties. However, the use of these ratings has so far been limited, and the global diffusion of rating systems is relatively slow. Moreover, both real estate developers and institutional investors are understandably uncertain about how far to go in implementing environmental investments, since the economic rationale for the development of sustainable buildings is based almost entirely on anecdotal evidence.

This paper provides the first systematic analysis of the impact of environmentallysustainable building practices upon economic outcomes as measured in the marketplace. We concentrate on commercial property, and we investigate the relationship between investments in energy efficiency in design and construction and the rents, the effective rents (that is, rents adjusted for building occupancy levels), and the selling prices commanded by these properties. We analyze a large sample of buildings, some of which have been certified as more energy efficient by independent and impartial rating services.

We assemble a national sample of U.S. office buildings which have been evaluated for energy efficiency by one of two leading agencies. For each building, we 
identify a control sample of nearby office buildings. For some 10,000 subject and control buildings, we relate contract rents, effective rents and selling prices to a set of objective hedonic characteristics of buildings, holding constant the locational characteristics of properties. We find that buildings with a "green rating" command rental rates that are roughly three percent higher per square foot than otherwise identical buildings controlling for the quality and the specific location of office buildings. Premiums in effective rents are even higher - above six percent. Selling prices of green buildings are higher by about 16 percent.

Beyond the average price or rental premium, our methodology also permits us to estimate the increment for each "green building" relative to the control buildings in its immediate geographic neighborhood. We find, for example, that the relative premium for "green buildings" is higher, ceteris paribus, in places where the economic premium for location is lower. That is, the percent increase in rent or value for a green building is systematically greater in smaller or lower-cost regions or in less expensive parts of metropolitan areas.

For a subsample of the buildings which have been certified as energy efficient by the Energy Star program, we obtained the data on energy usage reported to the Environmental Protection Agency as a part of the certification process. Within this population of certified "green buildings," we find that variations in market value are systematically related to the energy efficiency of buildings. This is strong evidence that the increment to market value attributable to its certification as "green" reflects more than an intangible labeling effect. 
Section II below provides a brief review of the emerging literature on corporate social responsibility and its relationship to environmentally sustainable buildings. In Section III we discuss the sources of ratings for the environmental aspects of buildings, and we describe the data used in our analysis, a unique body of micro data on the economic and hedonic characteristics of office buildings. We also discuss the energy usage data made available to us by the U.S. Environmental Protection Agency. Section IV presents our methodology and empirical results. Section V is a brief conclusion.

\section{Social Responsibility}

"Corporate social responsibility" (CSR, Sandra A. Waddock and Samuel B. Graves, 1997) has become a normative standard that describes firms' choices about inputs (e.g., the source of raw materials), internal processes (e.g., the treatment of employees), and publicity (e.g., community relations). Evaluations of the social responsibility of private firms have become an investment criterion for some investors, and it is estimated that $\$ 2.7$ trillion is currently allocated to "socially-screened" portfolios in the United States alone (Social Investment Forum, 2007). However, the economic rationale for investing in companies or investment funds that rank high in corporate social performance is a matter of debate, and there is no consensus about the financial performance of these investments (Joshua D. Margolis and James P. Walsh, 2003).

Companies with well-defined and aggressive CSR policies might be able to outperform others for several reasons: improved corporate reputation (Daniel B. Turban and Daniel W. Greening, 1997), less intrusion from activists and governmental organizations (David Baron, 2001, Thomas P. Lyon and John W. Maxwell, 2006), reduced threat of regulation (John W. Maxwell, Thomas P. Lyon, and Steven C. Hackett, 
2000), and improved profitability through lower input costs and higher employee productivity. The latter two represent the most tangible elements of corporate social responsibility.

In the real estate sector, these issues of eco-efficiency are confounded with straightforward capital budgeting decisions involving choices between the levels and types of initial investment and consequent operating inputs chosen to maximize investor returns. In this context, the investment in green buildings could lead to economic benefits in several distinct ways.

First, investments in energy efficiency at the time of construction or renovation may: save current resources expended on energy, water and waste disposal; decrease other operating costs; insure against future energy price increases; and simultaneously decrease greenhouse gas emissions. The financial benefits of energy savings and waste reduction are measurable, but existing empirical studies focus on environmental consequences rather than financial performance. For real estate, the evidence on energy savings in green buildings is typically based upon engineering studies of energy usage. There seems to be a consensus that a variety of capital expenditures improving energy efficiency in property are cost-effective at reasonable interest rates, given current and projected energy costs.

Second, an improved indoor environmental quality in green buildings might result in higher employee productivity. But while energy and waste savings can be measured fairly precisely, the relation between employee productivity and building design or operation is far more complicated. The financial impact of healthier and more comfortable green buildings is hard to assess, in part because the cost of poor indoor 
environmental quality (for example, lower productivity and higher absenteeism) may simply be hidden. However, there is popular discussion of the putative health and productivity costs that are imposed by poor indoor environmental quality in commercial buildings. ${ }^{1}$ In recognition of these assertions, largely undocumented, tenants may be willing to pay a higher rent for buildings in which indoor environmental quality is better.

Third, locating corporate activities in a green building may affect the corporate image of tenants. Leasing space in a green building may send a concrete signal of the social awareness, and of the superior social responsibility of the occupants. This may be important for some firms, and it may be a determinant of corporate reputation (Charles J. Frombrun and Mark Shanley, 1990). Favorable reputations may enable firms to charge premium prices (Benjamin Klein and Keith B. Leffler, 1981), to attract a better workforce (Turban and Greening, 1997), and to attract investors (Paul R. Milgrom and John Roberts, 1986). As a result, tenants may be willing to pay higher rents for green buildings.

Fourth, if tenants would prefer sustainable buildings, then sustainable buildings might have longer economic lives than conventional ones. This could also imply a lower volatility in market value - due to less environmental risk and better marketability leading to reduced risk premiums and higher valuations of the properties. Mark Orlitzky and John D. Benjamin (2001) address the relation between corporate social performance and risk; they argue that the better a firm's social reputation, the lower its total market risk. If this relationship holds for the real estate sector, building green may result in a

\footnotetext{
${ }^{1}$ See U.S. EPA Indoor Air Quality (2009) for more background information.
} 
lower cost of capital and a higher building valuation. So, even if green buildings did not command higher spot rents, they could still be valued higher.

Economists are quick to point out that many of these advantages could be obtained if energy inputs were appropriately priced (to reflect their social and environmental costs). Appropriate investments in energy efficiency would minimize lifecycle costs discounted at market rates, maximize developer returns, and correctly economize on energy costs (John M. Quigley, 1991). But to the extent that productivity, corporate image, and intangible or hard-to-measure returns are important, simple adjustments of input prices are just that - too simple.

If the economic benefits of building green for commercial property are indeed reflected in tenants' willingness to pay premiums on net rent for green spaces or in lower risk premiums for green buildings, this would enable investors to offset the higher initial investment required for sustainable buildings, or even to command higher risk-adjusted returns. However, for real estate investors, hard evidence on the financial performance of green buildings is limited and consists mainly of industry-initiated case studies. ${ }^{2}$ To persuade property owners, developers and investors in the global marketplace of the benefits of "eco-investment," the payoff from investment in green buildings needs to be identified in that same marketplace.

\footnotetext{
${ }^{2}$ An example is the report for California's Sustainable Building Task Force (2003) on the costs and financial benefits of green buildings. For a sample of 33 California buildings with green ratings, it was concluded that the financial benefits of green design were ten times as large as the incremental outlays to finance those green investments. However, the sources of the financial benefits identified in this case study are diverse, hard to quantify, and they were not verified by market transactions.
} 


\section{Data on Commercial Buildings}

In the U.S., there are two major programs that encourage the development of energy-efficient and sustainable buildings through systems of ratings to designate and publicize exemplary buildings. The Energy Star program is jointly sponsored by two Federal agencies, the U.S. Environmental Protection Agency, and the U.S. Department of Energy. Energy Star began in 1992 as a voluntary labeling program designed to identify and promote energy-efficient products in order to reduce greenhouse gas emissions. Energy Star labels were first applied to computers and computer equipment and were later extended to office equipment, to residential heating and cooling equipment, and to major appliances. The Energy Star label was extended to new homes in 1993 and has been promoted as an efficient way for consumers to identify builders as well as buildings constructed using energy-efficient methods. The Energy Star label is marketed as an indication of lower ownership costs, better energy performance, and higher home resale values. The label is also marketed as an indication of better environmental protection, and the Energy Star website for new homes stresses that "your home can be a greater source of pollution than your car." The Energy Star label was extended to commercial buildings in 1995, and the labeling program for these buildings began in 1999.

Nonresidential buildings can receive an Energy Star certification if the source energy use of the building (that is, the total of all energy used in the building), as certified by a professional engineer, achieves certain specified benchmark levels. The benchmark is chosen so that the label is awarded to the top quarter of all comparable buildings, ranked in terms of source energy efficiency. The Energy Star label is marketed as a commitment to conservation and environmental stewardship. But it is also touted as a vehicle for reducing building costs and for demonstrating superior management skill. 
Indeed, the Energy Star website draws attention to the relationship between energy conservation in buildings and other indicia of good "corporate governance."

As of June 2009, 7,338 buildings in the U.S. had been awarded the Energy Star designation, including 2,943 office buildings.

The U.S. Green Building Council (USGBC), a private nonprofit organization, has developed the LEED ("Leadership in Energy and Environmental Design") green building rating system to encourage the "adoption of sustainable green building and development practices." Since adoption in 1999, separate standards have been applied to new buildings and to existing structures. The requirements for certification of LEED buildings are substantially more complex than those for the award of an Energy Star rating, and additional points in the certification process are awarded for such factors as "site selection," "brownfield redevelopment," and the availability of "bicycle storage and changing rooms," as well as energy performance.

It is claimed that LEED-certified buildings have lower operating costs and increased asset values and provide healthier and safer environments for occupants. It is also noted that the award of a LEED designation "demonstrate[s] an owner's commitment to environmental stewardship and social responsibility."

As of June 2009, there were 2,706 buildings certified by the LEED Program of the USGBC, including 1,151 office buildings.

Energy-Star-rated buildings and LEED-rated buildings are identified by street address on the websites of Energy Star and the USGBC respectively. We matched the addresses of the rated buildings in these two programs as of September 2007 to the office buildings identified in the archives maintained by the CoStar Group. The CoStar service 
and the data files maintained by CoStar are advertised as "the most complete source of commercial real estate information in the U.S."3 Our match yielded 1,360 green office

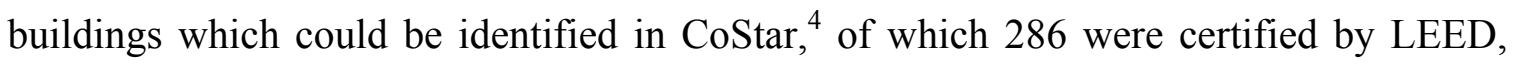
1,045 were certified by Energy Star, and 29 were certified by both LEED and Energy Star.

Figure 1 provides a geographic summary of our match between the Energy Starcertified commercial office buildings, the LEED-certified buildings, and the universe of commercial buildings identified in CoStar. The figure reports the number of certified commercial office buildings in each state, as well as an estimate of the fraction of office space in each state that has been rated for environmental sustainability. Calculations based on information from the CoStar database show that about three percent of U.S. office building space is green-labeled..$^{5}$ As the map indicates, in some states - notably Texas, Washington, and Minnesota - more than five percent of office buildings are rated. The incidence of green office space is almost nine percent in California - 122 million square feet of office space are labeled. In a large number of states, however, only a small

\footnotetext{
${ }^{3}$ The CoStar Group maintains an extensive micro database of approximately 2.4 million U.S. commercial properties, their locations, and hedonic characteristics, as well as the current tenancy and rental terms for the buildings. Of these 2.4 million commercial buildings, approximately 17 percent are offices, 22 percent are industrial properties, 34 percent is retail, 11 percent is land, and 12 percent is multifamily. A separate file is maintained of the recent sales of commercial buildings.

${ }^{4}$ In the September 2007 version of the CoStar database, green-rated buildings are separately identified. However, in matching the Energy Star and LEED-certified buildings by street address, we discovered that about a quarter of the buildings certified by Energy Star and LEED had not been recorded in the CoStar database. These missing observations are mostly owner-occupied green offices, implying that no rental data are available. Since property investors cannot invest in these buildings, we do not expect this to have an important effect on the results.

${ }^{5}$ Ratios based upon the CoStar data probably overstate the fraction of green office space in the U.S. inventory, since CoStar's coverage of smaller and older office buildings is less complete. The fraction of rated space in the U.S. is based on the certified office space per state as a fraction of total office space per state, as covered by CoStar. The fraction of the absolute number of office buildings with a green rating is smaller than the fraction of total office space, as green buildings are typically larger than the otherwise comparable non-green office building.
} 


\section{Figure 1}

Distribution of Green Office Buildings by State

(percent of the stock of office space)

2007

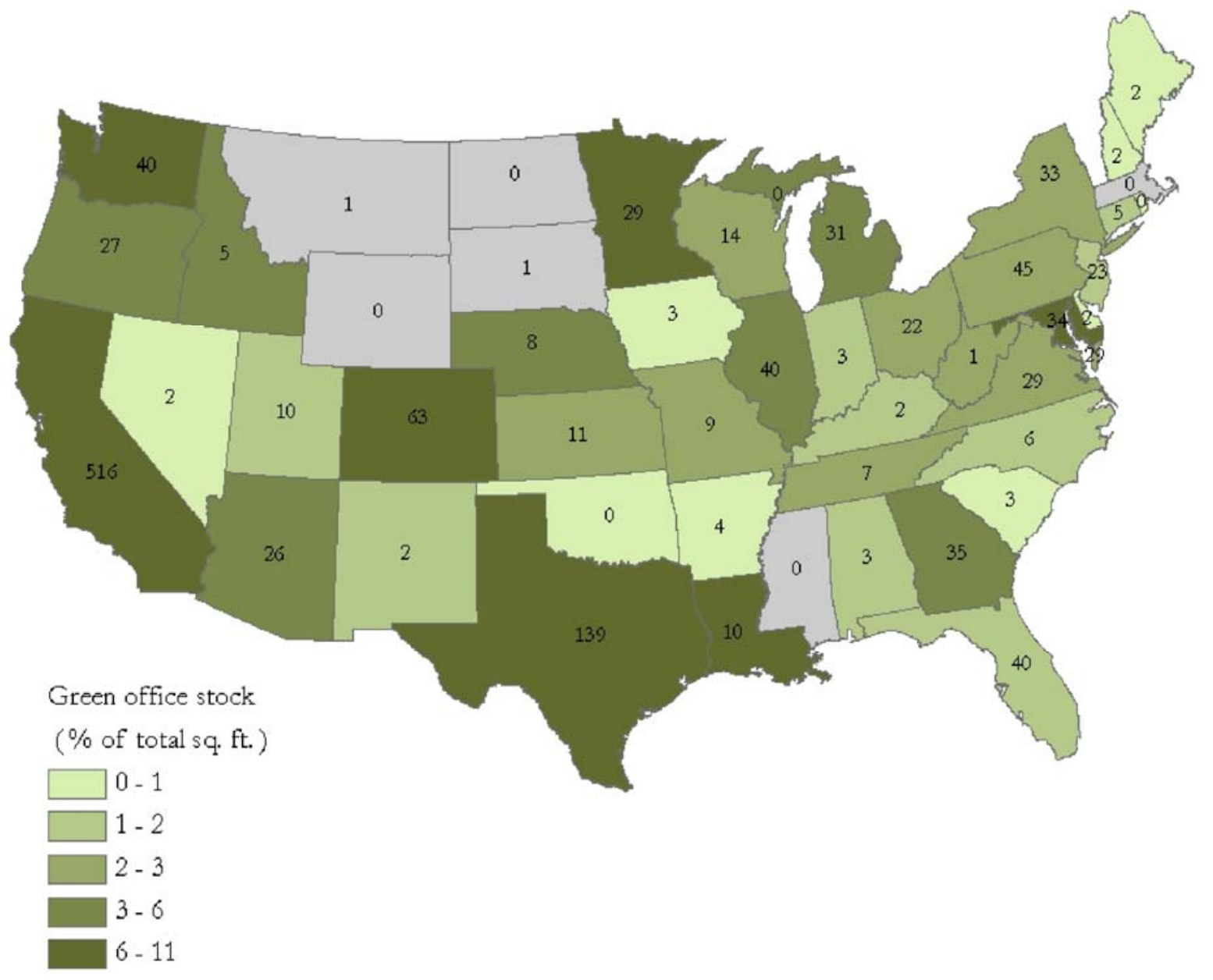

Notes:The number of green office buildings in each state is also reported.

Source: Costar and authors' calculations 
fraction of office space is certified by Energy Star or the USGBC. Apart from California, states with extreme temperatures are apparently more likely to have rated office buildings.

Of the 1,360 rated buildings identified in the CoStar database, current information about building characteristics and monthly rents were available for 694 buildings. In addition, 199 of these buildings were sold between 2004 and 2007. ${ }^{6}$ To investigate the effect of energy efficiency on the rents and values of commercial buildings, we matched each of the rated buildings in this sample to nearby commercial buildings in the same market. Based upon the latitude and longitude of each rated building, we used GIS techniques to identify all other office buildings in the CoStar database within a radius of one quarter mile. In this way, we created 893 (i.e., 694 plus 199) clusters of nearby office buildings. Each small cluster - 0.2 square miles - contains one rated building and at least one nonrated nearby building. On average, each cluster contains about 12 buildings. There are 8,182 commercial office buildings in the sample of green buildings and control buildings with rental data, and there are 1,816 buildings in the sample of buildings which have been sold.

\section{Empirical Analysis}

\section{A. The Premium for Labeled Buildings}

To investigate how the certification of energy efficiency influences the rent and value of commercial office buildings, we start with the standard valuation framework for commercial real estate. The sample of energy-rated office buildings and the control sample consisting of one-ormore nearby nonrated office buildings are used to estimate a semilog equation relating office rents (or selling prices) per square foot to the hedonic characteristics of the buildings (e.g., age, building quality, amenities provided, etc.) and the location of each building: 
(1a) $\log R_{\text {in }}=\alpha+\beta_{i} X_{i}+\sum_{n=1}^{N} \gamma_{n} c_{n}+\delta g_{i}+\varepsilon_{\text {in }}^{*}$

$$
\log R_{\text {in }}=\alpha+\beta_{i} X_{i}+\sum_{n=1}^{N} \gamma_{n} c_{n}+\sum_{n=1}^{N} \delta_{n}\left[c_{n} \cdot g_{i}\right]+\varepsilon_{i n}^{* *}
$$

In the formulation represented by equation (1a), the dependent variable is the logarithm of the rent per square foot $R_{i n}$ in commercial office building $i$ in cluster $n$. In other results presented, the dependent variable is the logarithm of effective rent per square foot (that is, the rent per square foot multiplied by the occupancy rate) or the selling price per square foot. $\mathbf{X}_{i}$ is a vector of the hedonic characteristics of building $i$. To control for regional differences in demand for office space, $\mathbf{X}_{i}$ also includes the percentage increase in employment in the service sector for the Core Based Statistical Area (CBSA) containing a cluster of a green building and its nearby controls. ${ }^{7}$ To control further for locational effects, $c_{n}$ is a dummy variable with a value of 1 if building $i$ is located in cluster $n$ and zero otherwise. ${ }^{8} g_{i}$ is a dummy variable with a value of 1 if building $i$ is rated by Energy Star or USGBC and zero otherwise. $\alpha, \beta_{i}, \gamma_{n}$ and $\delta$ are estimated coefficients, and $\varepsilon_{i n}$ is an error term. For the sample of rental properties in expression (1a), there are dummy variables for 694 separate locations which may affect office rents, one for each of the $N$ distinct 0.2 -square-mile clusters. The increment to rent associated with a rated building is

\footnotetext{
${ }^{6}$ We choose this interval, $2004-2007$, in part, because the formula for rating office buildings was unchanged throughout the period.

${ }^{7}$ For the rental sample, we use the employment growth in 2006; for the transaction sample, we use the employment growth in the year before the transaction date. These data are available from the Bureau of Labor Statistics (www.bls.gov).

${ }^{8}$ In this way, the specification recognizes the old adage about the three most important determinants of property valuation: "location, location, location."
} 
$\exp [\delta]$. For the sample of sold buildings, there are 199 location coefficients, one for each cluster, as well as dummy variables for the year of sale. ${ }^{9}$

In equation (1b), the locational measure is further generalized. In this formulation, the effect of a green rating on commercial rents or selling prices may vary separately for green buildings in each of the 694 clusters in the rental sample and for green buildings in each of the 199 clusters in the sample of sold buildings. The increment to rent or market value for the green building in cluster $n$, relative to the rents of the other buildings in cluster $n$, is $\exp \left[\delta_{n}\right]$.

Table 1 presents the basic results for the rental sample, relating the logarithm of rent per square foot in commercial office buildings to a set of hedonic and other characteristics of the buildings. Results are presented for ordinary least squares regression models corrected for heteroskedasticity (Halbert White, 1980). Column (1) reports a basic model relating rent to building quality, measured by class designation, size, and occupancy rate. The regression, based upon 8,182 observations on buildings ${ }^{10}$ explains some 71 percent of log rent. When rents are quoted gross, they are about five percent higher than when they are quoted net of utilities. Higher quality buildings, as measured by building class, command a substantial premium. Rent in a class A building is about 23 percent higher than in a class $\mathrm{C}$ building, and about 13 percent higher than in a class B building. Rent is significantly higher in larger buildings, as measured by

\footnotetext{
${ }^{9}$ Our formulation thus generalizes the treatment of spatial variation in the real estate asset pricing literature where spatial variation is commonly analyzed in one of three ways: first, by including location dummies for submarkets (John L. Glasscock, Shirin Jahanian and C. F. Sirmans, 1990, William C. Wheaton and Raymond Torto, 1994); second, by studying a specific MSA or small region to isolate the influence of spatial variation (Kenneth T. Rosen, 1984, Brian Webb and Jeffrey D. Fisher, 1996, Åke Gunnelin and Bo Söderberg, 2003); or else by using Geographic Information System methods to specify the distance of a property to specific locations, for example the CBD, airport, or railway station (Rena Sivitanidou, 1995, Christopher R. Bollinger Keith R. Ihlanfeldt, and David. R. Bowes, 1998, V. Attila Öven and Dilek Pekdemir, 2006). Our analysis generalizes these methods by treating each of the small geographic clusters as distinct.

${ }^{10}$ That is, 694 rated buildings and 7,488 control buildings, each located within 1,300 feet of a rated building.
} 
Table 1

Regression Results

Commercial Office Rents and Green Ratings

(dependent variable: logarithm of rent in dollars per square foot)

\begin{tabular}{|c|c|c|c|c|c|}
\hline & (1) & (2) & (3) & (4) & (5) \\
\hline Green Rating $(1=$ yes $)$ & $\begin{array}{l}0.035 \\
{[0.009]^{* * *}}\end{array}$ & & $\begin{array}{l}0.033 \\
{[0.009]^{* * *}}\end{array}$ & $\begin{array}{l}0.028 \\
{[0.009]^{* * *}}\end{array}$ & \\
\hline Energy Star $(1=$ yes $)$ & & $\begin{array}{l}0.033 \\
{[0.009]^{* * *}}\end{array}$ & & & \\
\hline $\operatorname{LEED}(1=$ yes $)$ & & $\begin{array}{c}0.052 \\
{[0.036]}\end{array}$ & & & \\
\hline Building Size (millions of sq. $\mathrm{ft}$.) & $\begin{array}{l}0.113 \\
{[0.019]^{* * *}}\end{array}$ & $\begin{array}{l}0.113 \\
{[0.019]^{* * *}}\end{array}$ & $\begin{array}{l}0.102 \\
{[0.019]^{* * *}}\end{array}$ & $\begin{array}{l}0.111 \\
{[0.021]^{* * *}}\end{array}$ & $\begin{array}{l}0.111 \\
{[0.023]^{* * *}}\end{array}$ \\
\hline Fraction Occupied & $\begin{array}{c}0.020 \\
{[0.016]}\end{array}$ & $\begin{array}{c}0.020 \\
{[0.016]}\end{array}$ & $\begin{array}{c}0.020 \\
{[0.016]}\end{array}$ & $\begin{array}{c}0.011 \\
{[0.016]}\end{array}$ & $\begin{array}{c}0.004 \\
{[0.017]}\end{array}$ \\
\hline Building Class: & & & & & \\
\hline Class A $(1=$ yes $)$ & $\begin{array}{l}0.231 \\
{[0.012]^{* * *}}\end{array}$ & $\begin{array}{l}0.231 \\
{[0.012]^{* * *}}\end{array}$ & $\begin{array}{l}0.192 \\
{[0.014]^{* * *}}\end{array}$ & $\begin{array}{l}0.173 \\
{[0.015]^{* * *}}\end{array}$ & $\begin{array}{l}0.173 \\
{[0.017]^{* * *}}\end{array}$ \\
\hline Class B $(1=$ yes $)$ & $\begin{array}{l}0.101 \\
{[0.011]^{* * *}}\end{array}$ & $\begin{array}{l}0.101 \\
{[0.011]^{* * *}}\end{array}$ & $\begin{array}{l}0.092 \\
{[0.011]^{* * *}}\end{array}$ & $\begin{array}{l}0.083 \\
{[0.011]^{* * *}}\end{array}$ & $\begin{array}{l}0.082 \\
{[0.012]^{* * *}}\end{array}$ \\
\hline Net Contract $(1=$ yes $)$ & $\begin{array}{l}-0.047 \\
{[0.013]^{* * *}}\end{array}$ & $\begin{array}{l}-0.047 \\
{[0.013]^{* * *}}\end{array}$ & $\begin{array}{l}-0.050 \\
{[0.013] * * *}\end{array}$ & $\begin{array}{l}-0.051 \\
{[0.013]^{* * *}}\end{array}$ & $\begin{array}{l}-0.057 \\
{[0.014]^{* * *}}\end{array}$ \\
\hline Employment Growth (fraction) & $\begin{array}{l}0.608 \\
{[0.171]^{* * *}}\end{array}$ & $\begin{array}{l}0.608 \\
{[0.171]^{* * *}}\end{array}$ & $\begin{array}{l}0.613 \\
{[0.187]^{* * *}}\end{array}$ & $\begin{array}{l}0.609 \\
{[0.189]^{* * *}}\end{array}$ & $\begin{array}{c}0.874 \\
{[0.054]^{* * *}}\end{array}$ \\
\hline Age: & & & & & \\
\hline$<10$ years & & & $\begin{array}{l}0.118 \\
{[0.016]^{* * *}}\end{array}$ & $\begin{array}{l}0.131 \\
{[0.017]^{* * *}}\end{array}$ & $\begin{array}{l}0.132 \\
{[0.019]^{* * *}}\end{array}$ \\
\hline $10-20$ years & & & $\begin{array}{l}0.079 \\
{[0.014]^{* * *}}\end{array}$ & $\begin{array}{l}0.085 \\
{[0.014]^{* * *}}\end{array}$ & $\begin{array}{l}0.083 \\
{[0.015]^{* * *}}\end{array}$ \\
\hline $20-30$ years & & & $\begin{array}{l}0.047 \\
{[0.013]^{* * *}}\end{array}$ & $\begin{array}{l}0.049 \\
{[0.013]^{* * *}}\end{array}$ & $\begin{array}{l}0.049 \\
{[0.014]^{* * *}}\end{array}$ \\
\hline $30-40$ years & & & $\begin{array}{l}0.043 \\
{[0.011]^{* * *}}\end{array}$ & $\begin{array}{l}0.044 \\
{[0.011]^{* * *}}\end{array}$ & $\begin{array}{l}0.044 \\
{[0.012]^{* * *}}\end{array}$ \\
\hline Renovated $(1=$ yes $)$ & & & $\begin{array}{l}-0.008 \\
{[0.009]}\end{array}$ & $\begin{array}{l}-0.008 \\
{[0.009]}\end{array}$ & $\begin{array}{l}-0.010 \\
{[0.010]}\end{array}$ \\
\hline Stories: & & & & & \\
\hline Intermediate $(1=$ yes $)$ & & & & $\begin{array}{c}0.009 \\
{[0.009]}\end{array}$ & $\begin{array}{c}0.008 \\
{[0.010]}\end{array}$ \\
\hline $\operatorname{High}(1=$ yes $)$ & & & & $\begin{array}{l}-0.029 \\
{[0.014]^{* *}}\end{array}$ & $\begin{array}{l}-0.032 \\
{[0.016]^{* *}}\end{array}$ \\
\hline Amenities $(1=y e s)$ & & & & $\begin{array}{l}0.047 \\
{[0.007]^{* * *}}\end{array}$ & $\begin{array}{l}0.054 \\
{[0.008]^{* * *}}\end{array}$ \\
\hline Constant & $\begin{array}{l}2.741 \\
{[0.113]^{* * *}}\end{array}$ & $\begin{array}{l}2.742 \\
{[0.114]^{* * *}}\end{array}$ & $\begin{array}{l}2.718 \\
{[0.126]^{* * *}}\end{array}$ & $\begin{array}{l}2.725 \\
{[0.127] * * *}\end{array}$ & $\begin{array}{c}2.564 \\
{[0.022]^{* * *}}\end{array}$ \\
\hline Sample Size & 8182 & 8182 & 8182 & 8182 & 8182 \\
\hline $\mathrm{R}^{2}$ & 0.71 & 0.71 & 0.72 & 0.72 & 0.74 \\
\hline Adjusted $\mathrm{R}^{2}$ & 0.69 & 0.69 & 0.69 & 0.69 & 0.68 \\
\hline
\end{tabular}

Notes:Each regression also includes 694 dummy variables, one for each locational cluster.

Regression (5) also includes an additional 694 dummy variables, one for each green building in the sample.

Standard errors are in brackets. Significance at the $0.10,0.05$, and 0.01 levels are indicated by *, **, and ***, respectively. 
square footage, but the magnitude is quite small, about one percent for an additional 100,000 square feet. Employment growth in the service sector has a strong effect on rents; a one percent increase in employment in the service sector leads to an increase of 0.6 percent in rent. The coefficients for the 694 dummy variables for location are highly significant, with an F-ratio of 23.49. Importantly, holding other factors constant, the estimated rent premium for a green building is about 3.5 percent.

In column (2), the green certification is distinguished by its Energy Star or its LEED rating. The estimated coefficient for the LEED rating indicates a premium of 5.2 percent in commercial rents, but this is insignificantly different from zero. The Energy Star rating is associated with rents higher by 3.3 percent. This difference is highly significant.

In column (3), a set of variables measuring building age in four categories is added to the model. The coefficients of the other variables are quite stable. The results indicate that there is a substantial premium associated with newer buildings. Ceteris paribus, rents in a commercial office building less than ten years old are 12 percent higher than those in a building more than 40 years old.

Column (4) adjusts for differences in the number of stories and for the presence of on-site amenities. There is evidence that rents in very tall buildings, greater than 20 stories, are slightly lower. On-site amenities are associated with higher office rents.

Importantly, when the specification of the hedonic variables is changed in various ways, the magnitude and the statistical significance of the green rating is unchanged. Ceteris paribus, the rent in a green building is significantly higher by 2.8 to 3.5 percent than in an unrated building. 
Column (5) presents the results from estimation of equation (1b). In this formulation, the specification includes 1,388 dummy variables (not reported in the table) - one for each of the 694 clusters, and one for the specific green building identified in each cluster. When the model is expanded in this way, the coefficients of the other variables are unchanged, and the explained variance is slightly larger. Of course, in this more general specification, the rent premium for a green building varies in magnitude in each separate cluster. In Section IV.B, we provide further analysis of the increments estimated for individual green buildings.

Table 2 presents the results when the dependent variable is measured by the logarithm of effective rent. When endogenous rent-setting policies are taken into account, ${ }^{11}$ the results suggest that the effect of a green rating is even larger. In the simplest model, column (1), the statistical results suggest that a green rating is associated with a ten percent increase in effective rent. In the regression reported in column (2), the dummy variable representing a LEED-rated building indicates a premium of nine percent, and the t-ratio (1.8) approaches significance at conventional levels ( $\mathrm{p}=0.07)$. When the other hedonic characteristics and amenities of buildings are accounted for in column (4) - as far as possible - the results still indicate an effective premium of more than six percent for rated buildings. Taken together, the results reported in Tables 1 and 2 suggest that the occupancy rate of green buildings is about seven percent higher than in otherwise comparable nongreen buildings.

Table 3 presents analogous results based upon the sample of 199 green office buildings sold in the 2004-2007 period and the control sample of 1,617 nongreen buildings sold within a quarter mile of those green buildings. These models explain a smaller fraction of the variation in

\footnotetext{
${ }^{11}$ We may expect property owners to adopt differing asking rent strategies. Ceteris paribus, landlords who charge higher rents will experience higher vacancy rates.
} 


\section{Table 2}

\section{Regression Results}

Commercial Office Rents and Green Ratings

(dependent variable: logarithm of effective rent in dollars per square foot)

\begin{tabular}{|c|c|c|c|c|c|}
\hline & (1) & (2) & (3) & (4) & (5) \\
\hline Green Rating $(1=$ yes $)$ & $\begin{array}{c}0.100 \\
{[0.016]^{* * *}}\end{array}$ & & $\begin{array}{c}0.082 \\
{[0.024]^{* * *}}\end{array}$ & $\begin{array}{c}0.064 \\
{[0.023]^{* * *}}\end{array}$ & \\
\hline Energy Star $(1=$ yes $)$ & & $\begin{array}{l}0.100 \\
{[0.016]^{* * *}}\end{array}$ & & & \\
\hline $\operatorname{LEED}(1=$ yes $)$ & & $\begin{array}{c}0.094 \\
{[0.052]^{*}}\end{array}$ & & & \\
\hline Building Size (millions of sq. $\mathrm{ft}$.) & $\begin{array}{c}0.261 \\
{[0.028]^{* * *}}\end{array}$ & $\begin{array}{l}0.261 \\
{[0.028]^{* * *}}\end{array}$ & $\begin{array}{c}0.235 \\
{[0.027]^{* * *}}\end{array}$ & $\begin{array}{l}0.189 \\
{[0.027]^{* * *}}\end{array}$ & $\begin{array}{l}0.193 \\
{[0.030]^{* * *}}\end{array}$ \\
\hline \multicolumn{6}{|l|}{ Building Class: } \\
\hline Class A $(1=$ yes $)$ & $\begin{array}{l}0.408 \\
{[0.028]^{* * *}}\end{array}$ & $\begin{array}{l}0.408 \\
{[0.028]^{* * *}}\end{array}$ & $\begin{array}{c}0.340 \\
{[0.029]^{* * *}}\end{array}$ & $\begin{array}{c}0.229 \\
{[0.030]^{* * *}}\end{array}$ & $\begin{array}{c}0.226 \\
{[0.033]^{* * *}}\end{array}$ \\
\hline Class B $(1=$ yes $)$ & $\begin{array}{l}0.226 \\
{[0.027]^{* * *}}\end{array}$ & $\begin{array}{l}0.226 \\
{[0.027]^{* * *}}\end{array}$ & $\begin{array}{l}0.203 \\
{[0.027] * * *}\end{array}$ & $\begin{array}{l}0.152 \\
{[0.026]^{* * *}}\end{array}$ & $\begin{array}{c}0.149 \\
{[0.028]^{* * *}}\end{array}$ \\
\hline Net Contract $(1=$ yes $)$ & $\begin{array}{c}0.015 \\
{[0.024]}\end{array}$ & $\begin{array}{c}0.014 \\
{[0.024]}\end{array}$ & $\begin{array}{c}0.010 \\
{[0.024]}\end{array}$ & $\begin{array}{c}0.009 \\
{[0.024]}\end{array}$ & $\begin{array}{c}0.016 \\
{[0.028]}\end{array}$ \\
\hline Employment Growth (fraction) & $\begin{array}{c}0.765 \\
{[0.312]^{* *}}\end{array}$ & $\begin{array}{c}0.756 \\
{[0.322]^{* *}}\end{array}$ & $\begin{array}{c}0.773 \\
{[0.293]^{* *}}\end{array}$ & $\begin{array}{c}0.682 \\
{[0.308]^{* *}}\end{array}$ & $\begin{array}{c}0.468 \\
{[0.421]}\end{array}$ \\
\hline \multicolumn{6}{|l|}{ Age: } \\
\hline$<10$ years & & & $\begin{array}{l}0.134 \\
{[0.045]^{* * *}}\end{array}$ & $\begin{array}{l}0.177 \\
{[0.044]^{* * *}}\end{array}$ & $\begin{array}{c}0.149 \\
{[0.054]^{* * *}}\end{array}$ \\
\hline $10-20$ years & & & $\begin{array}{l}0.141 \\
{[0.025] * * *}\end{array}$ & $\begin{array}{l}0.146 \\
{[0.025]^{* * *}}\end{array}$ & $\begin{array}{c}0.150 \\
{[0.028]^{* * *}}\end{array}$ \\
\hline $20-30$ years & & & $\begin{array}{l}0.113 \\
{[0.023]^{* * *}}\end{array}$ & $\begin{array}{l}0.112 \\
{[0.023]^{* * *}}\end{array}$ & $\begin{array}{c}0.128 \\
{[0.025]^{* * *}}\end{array}$ \\
\hline $30-40$ years & & & $\begin{array}{l}0.097 \\
{[0.018] * * *}\end{array}$ & $\begin{array}{l}0.090 \\
{[0.018]^{* * *}}\end{array}$ & $\begin{array}{c}0.089 \\
{[0.020]^{* * *}}\end{array}$ \\
\hline Renovated $(1=$ yes $)$ & & & $\begin{array}{c}0.019 \\
{[0.018]}\end{array}$ & $\begin{array}{c}0.016 \\
{[0.018]}\end{array}$ & $\begin{array}{c}0.022 \\
{[0.019]}\end{array}$ \\
\hline \multicolumn{6}{|l|}{ Stories: } \\
\hline Intermediate $(1=$ yes $)$ & & & & $\begin{array}{l}0.145 \\
{[0.021]^{* * *}}\end{array}$ & $\begin{array}{c}0.156 \\
{[0.024]^{* * *}}\end{array}$ \\
\hline $\operatorname{High}(1=$ yes $)$ & & & & $\begin{array}{l}0.086 \\
{[0.025]^{* * *}}\end{array}$ & $\begin{array}{c}0.090 \\
{[0.029]^{* * *}}\end{array}$ \\
\hline Amenities ( $1=$ yes $)$ & & & & $\begin{array}{l}0.118 \\
{[0.015]^{* * *}}\end{array}$ & $\begin{array}{c}0.124 \\
{[0.016]^{* * *}}\end{array}$ \\
\hline Constant & $\begin{array}{c}2.151 \\
{[0.029]^{* * *}}\end{array}$ & $\begin{array}{l}2.158 \\
{[0.059]^{* * *}}\end{array}$ & $\begin{array}{l}2.093 \\
{[0.050]^{* * *}}\end{array}$ & $\begin{array}{l}2.187 \\
{[0.050]^{* * *}}\end{array}$ & $\begin{array}{l}2.299 \\
{[0.060]^{* * *}}\end{array}$ \\
\hline Sample Size & 8182 & 8182 & 8182 & 8182 & 8182 \\
\hline $\mathrm{R}^{2}$ & 0.47 & 0.47 & 0.47 & 0.48 & 0.51 \\
\hline Adjusted $\mathrm{R}^{2}$ & 0.42 & 0.42 & 0.42 & 0.43 & 0.41 \\
\hline
\end{tabular}

Notes:Each regression also includes 694 dummy variables, one for each locational cluster.

Regression (5) also includes an additional 694 dummy variables, one for each green building in the sample.

Standard errors are in brackets. Significance at the $0.10,0.05$, and 0.01 levels are indicated by *, **, and ***, respectively. 


\section{Table 3}

Regression Results

Office Sales Prices and Green Ratings 2004 - 2007

(dependent variable: logarithm of sales price in dollars per square foot)

\begin{tabular}{|c|c|c|c|c|c|}
\hline & (1) & (2) & (3) & (4) & (5) \\
\hline Green Rating $(1=$ yes $)$ & $\begin{array}{c}0.168 \\
{[0.051]^{* * *}}\end{array}$ & & $\begin{array}{c}0.158 \\
{[0.052]^{* * *}}\end{array}$ & $\begin{array}{c}0.165 \\
{[0.052]^{* * *}}\end{array}$ & \\
\hline Energy Star $(1=$ yes $)$ & & $\begin{array}{l}0.191 \\
{[0.052]^{* * *}}\end{array}$ & & & \\
\hline $\operatorname{LEED}(1=$ yes $)$ & & $\begin{array}{c}0.113 \\
{[0.172]}\end{array}$ & & & \\
\hline Building Size (millions of sq. ft.) & $\begin{array}{c}0.171 \\
{[0.090]^{*}}\end{array}$ & $\begin{array}{c}0.167 \\
{[0.089]^{*}}\end{array}$ & $\begin{array}{c}0.104 \\
{[0.089]}\end{array}$ & $\begin{array}{c}0.200 \\
{[0.108]^{*}}\end{array}$ & $\begin{array}{c}0.192 \\
{[0.125]}\end{array}$ \\
\hline Building Class: & & & & & \\
\hline Class A $(1=$ yes $)$ & $\begin{array}{c}0.164 \\
{[0.066]^{* *}}\end{array}$ & $\begin{array}{c}0.161 \\
{[0.066]^{* *}}\end{array}$ & $\begin{array}{c}0.032 \\
{[0.078]}\end{array}$ & $\begin{array}{c}0.104 \\
{[0.084]}\end{array}$ & $\begin{array}{c}0.143 \\
{[0.099]}\end{array}$ \\
\hline Class B $(1=$ yes $)$ & $\begin{array}{l}-0.188 \\
{[0.051]^{* * *}}\end{array}$ & $\begin{array}{l}-0.187 \\
{[0.051] * * *}\end{array}$ & $\begin{array}{l}-0.216 \\
{[0.057]^{* * *}}\end{array}$ & $\begin{array}{l}-0.184 \\
{[0.058]^{* * *}}\end{array}$ & $\begin{array}{l}-0.183 \\
{[0.064]^{* * *}}\end{array}$ \\
\hline Employment Growth (fraction) & $\begin{array}{l}-0.005 \\
{[0.004]}\end{array}$ & $\begin{array}{l}-0.005 \\
{[0.004]}\end{array}$ & $\begin{array}{l}-0.004 \\
{[0.005]}\end{array}$ & $\begin{array}{l}-0.006 \\
{[0.005]}\end{array}$ & $\begin{array}{l}-0.006 \\
{[0.005]}\end{array}$ \\
\hline Age: & & & & & \\
\hline$<10$ years & & & $\begin{array}{c}0.201 \\
{[0.149]}\end{array}$ & $\begin{array}{c}0.207 \\
{[0.147]}\end{array}$ & $\begin{array}{c}0.161 \\
{[0.207]}\end{array}$ \\
\hline $10-20$ years & & & $\begin{array}{l}0.196 \\
{[0.099]^{* *}}\end{array}$ & $\begin{array}{c}0.224 \\
{[0.100]^{* *}}\end{array}$ & $\begin{array}{c}0.226 \\
{[0.124]^{*}}\end{array}$ \\
\hline $20-30$ years & & & $\begin{array}{l}0.248 \\
{[0.070]^{* * *}}\end{array}$ & $\begin{array}{l}0.276 \\
{[0.070]^{* * *}}\end{array}$ & $\begin{array}{l}0.288 \\
{[0.081]^{* * *}}\end{array}$ \\
\hline $30-40$ years & & & $\begin{array}{l}0.226 \\
{[0.073]^{* * *}}\end{array}$ & $\begin{array}{l}0.251 \\
{[0.075]^{* * *}}\end{array}$ & $\begin{array}{c}0.281 \\
{[0.090]^{* * *}}\end{array}$ \\
\hline Renovated $(1=$ yes $)$ & & & $\begin{array}{l}-0.096 \\
{[0.046]^{* *}}\end{array}$ & $\begin{array}{l}-0.087 \\
{[0.046]^{*}}\end{array}$ & $\begin{array}{l}-0.071 \\
{[0.053]}\end{array}$ \\
\hline Stories: & & & & & \\
\hline $\operatorname{High}(1=$ yes $)$ & & & & $\begin{array}{l}-0.185 \\
{[0.092]^{* *}}\end{array}$ & $\begin{array}{l}-0.232 \\
{[0.113]^{* *}}\end{array}$ \\
\hline Intermediate $(1=$ yes $)$ & & & & $\begin{array}{l}-0.183 \\
{[0.057]^{* * *}}\end{array}$ & $\begin{array}{l}-0.189 \\
{[0.067]^{* * *}}\end{array}$ \\
\hline Amenities (1=yes) & & & & $\begin{array}{l}-0.043 \\
{[0.049]}\end{array}$ & $\begin{array}{l}-0.048 \\
{[0.058]}\end{array}$ \\
\hline Year of Sale: & & & & & \\
\hline $2006(1=$ yes $)$ & $\begin{array}{c}0.015 \\
{[0.060]}\end{array}$ & $\begin{array}{c}0.017 \\
{[0.060]}\end{array}$ & $\begin{array}{c}0.021 \\
{[0.060]}\end{array}$ & $\begin{array}{c}0.016 \\
{[0.060]}\end{array}$ & $\begin{array}{c}0.048 \\
{[0.071]}\end{array}$ \\
\hline $2005(1=$ yes $)$ & $\begin{array}{l}-0.040 \\
{[0.056]}\end{array}$ & $\begin{array}{l}-0.039 \\
{[0.056]}\end{array}$ & $\begin{array}{l}-0.039 \\
{[0.056]}\end{array}$ & $\begin{array}{l}-0.048 \\
{[0.055]}\end{array}$ & $\begin{array}{l}-0.034 \\
{[0.065]}\end{array}$ \\
\hline $2004(1=$ yes $)$ & $\begin{array}{l}-0.177 \\
{[0.067]^{* * *}}\end{array}$ & $\begin{array}{l}-0.175 \\
{[0.067] * * *}\end{array}$ & $\begin{array}{l}-0.173 \\
{[0.067]^{* *}}\end{array}$ & $\begin{array}{l}-0.200 \\
{[0.067]^{* * *}}\end{array}$ & $\begin{array}{l}-0.174 \\
{[0.078]^{* *}}\end{array}$ \\
\hline Constant & $\begin{array}{l}5.314 \\
{[0.091]^{* * *}}\end{array}$ & $\begin{array}{l}5.317 \\
{[0.091]^{* * *}}\end{array}$ & $\begin{array}{l}5.269 \\
{[0.151]^{* * *}}\end{array}$ & $\begin{array}{l}5.406 \\
{[0.160]^{* * *}}\end{array}$ & $\begin{array}{l}5.401 \\
{[0.220]^{* * *}}\end{array}$ \\
\hline Sample Size & 1816 & 1816 & 1816 & 1816 & 1816 \\
\hline $\mathrm{R}^{2}$ & 0.43 & 0.43 & 0.44 & 0.44 & 0.49 \\
\hline Adjusted $\mathrm{R}^{2}$ & 0.35 & 0.35 & 0.36 & 0.37 & 0.34 \\
\hline
\end{tabular}

Notes:Each regression also includes 199 dummy variables, one for each locational cluster.

Regression (5) also includes an additional 199 dummy variables, one for each green building in the sample.

Standard errors are in brackets. Significance at the $0.10,0.05$, and 0.01 levels are indicated by *, **, and ***, respectively. 
the dependent variable, the logarithm of selling price per square foot, but the qualitative results are similar. For each of the specifications reported, the variable reflecting certification of a green building is highly significant. The transaction premiums for green buildings are, ceteris paribus, 15.8 to 16.8 percent higher than for nonrated buildings. When the certification is reported separately for the Energy Star and the LEED systems, there is no evidence that the latter certification is associated with higher selling prices. There is some evidence that selling prices per square foot are higher when buildings are larger, and when they are of higher quality (as measured by class rating). It appears that buildings with fewer stories sell for higher prices per square foot. Buildings sold in 2004 were lower in price by 17-20 percent compared to buildings sold in 2007.

The statistical results are broadly consistent across the models of rent and value determination. For example, the average effective rent for the control buildings in the rental sample of office buildings is $\$ 23.51$ per square foot. At the average size of these buildings and from Table 2, the estimated annual rent increment for a green building is approximately $\$ 329,000$. At prevailing capitalization rates of six percent, the incremental value of a green building is estimated to be about $\$ 5.5$ million more than the value of a comparable unrated building nearby. The average selling price for the control buildings in the sample of buildings sold in the 2004-2007 period is $\$ 34.73$ million. From Table 3, ceteris paribus, the incremental value of a green building is estimated to be about $\$ 5.7$ million more than the value of a comparable unrated building nearby.

The results reported in Tables 1, 2, and 3 are robust to other variations in the hedonic characteristics included on the right-hand side in the vector $\mathbf{X}$. They are not robust to the exclusion of the dummy variables identifying the neighborhoods in which the sample and control 
properties are located. However, the average quality of the green buildings is somewhat higher than the quality of the nongreen buildings in the clustered samples. Green buildings are slightly taller, and they are substantially larger. Because they are older, the control buildings are more likely to have been renovated than the green buildings in each cluster. We made additional efforts to estimate the premium for green buildings by identifying only the most "comparable" green and nongreen buildings in each cluster. In these comparisons, green and nongreen buildings are matched by propensity scores (Paul R. Rosenbaum and Donald B. Rubin, 1983), estimated separately by metropolitan area according to several specifications. The results of these comparisons, based conservatively (see Dan A. Black and Jeffrey Smith 2004) on the identification of "nearest neighbors" (thus much smaller samples), are consistent with the regression results based on larger samples reported in Tables 1,2, and 3. Rents and selling prices are estimated to be significantly higher for green buildings than for the most "comparable" nongreen buildings. These comparisons hold for a variety of stratifications of the sample of green and control buildings (e.g., large metropolitan areas). The comparisons are reported in detail in the longer version of this paper, available at http://urbanpolicy.berkeley.edu/research.htm.

The distribution of green-rated buildings is not random within urban areas in the U.S., and if this is not taken into account explicitly, statistical analyses can be highly misleading. Figure 2 illustrates this point. It presents the joint frequency distribution of the dummy variables estimated for each cluster and the dummy variables estimated for the premium for the green building in that cluster. (These are the coefficients estimated for clusters and for green buildings in equation 1b.) This relationship is presented separately for the premium in effective rents and in market values. An inverse relationship between any cluster premium and its associated green 
Figure 2

Location Increments vs

Increments for Energy Efficiency

A. Effective Rent

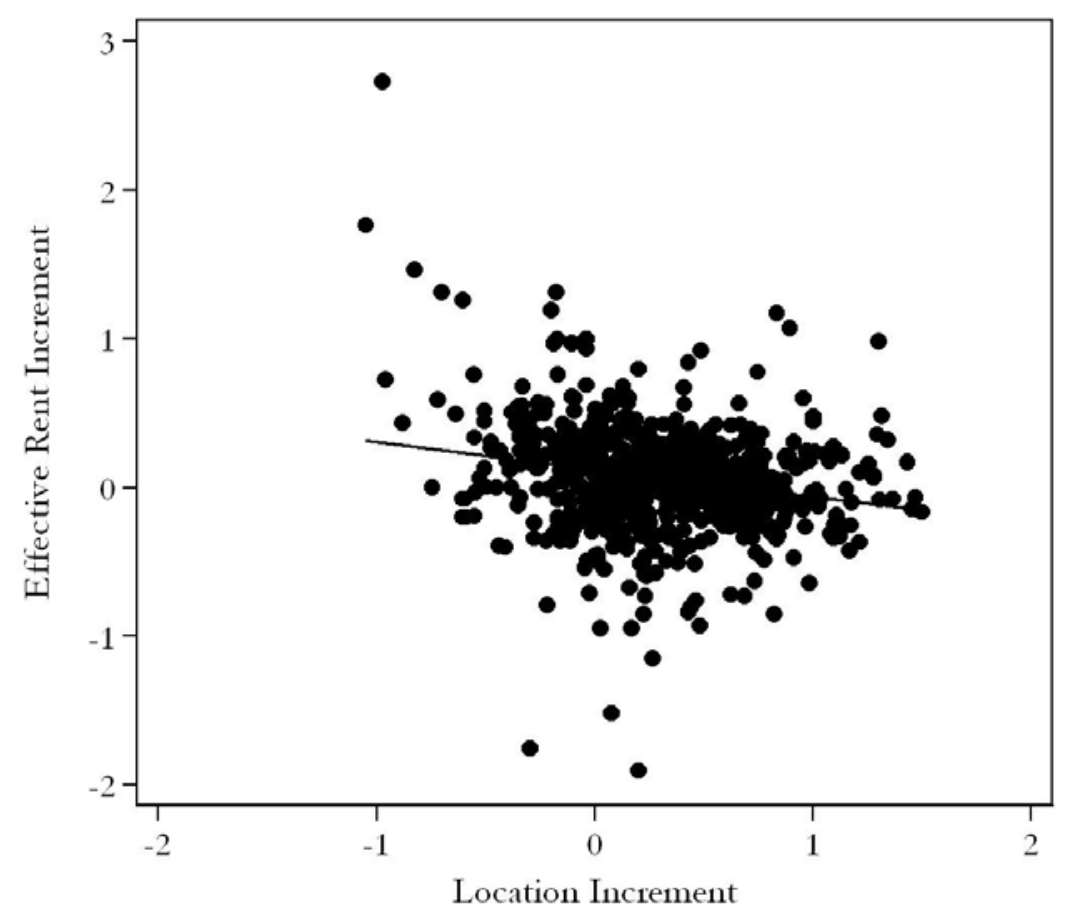

B. Market Value

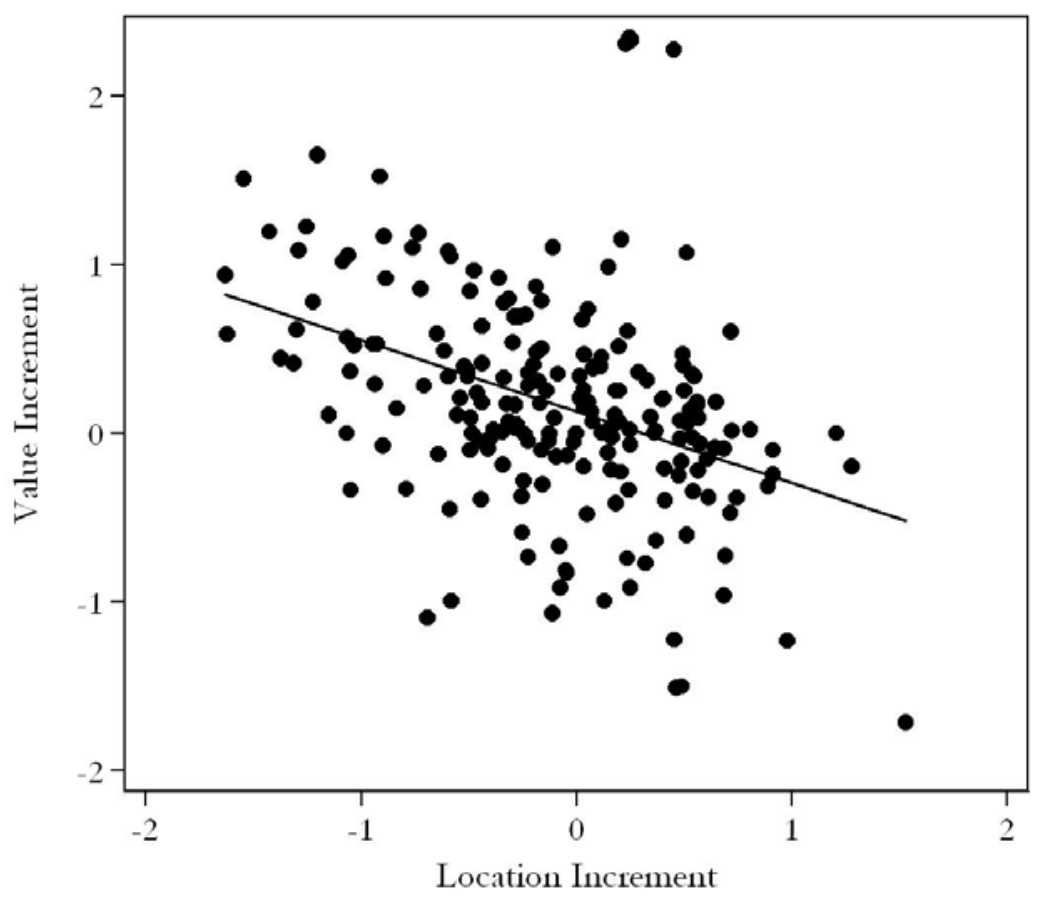


premium is clearly apparent. The correlation coefficient between cluster and green increments is significantly different from zero at the one percent level. This suggests that the premium for a green building, relative to nearby buildings, tends to be larger in smaller markets and regions and in the more peripheral parts of larger metropolitan areas, where location rents are lower. Apparently, a green label for a building adds proportionately less in value at a prime location, in some part because land rents are higher (and utility costs are thus a smaller component of rent). But the label may also serve as an important signal in an otherwise lower-quality location.

\section{B. The Premium for Energy Efficiency}

As demonstrated in the previous section, there is a statistically significant and rather large premium in rent and market value for green labeled buildings. The statistical analysis does not identify the source of this premium, or the extent to which the signal about energy efficiency is important relative to the other potential signals provided by a building of sufficient quality to earn a label. But the estimated premiums do vary within the stock of Energy-Star-rated labeled buildings - which are all certified to be in the top quarter of comparable buildings in terms of source energy efficiency.

Analysis of the coefficients estimating a separate premium for each green building, relative to its cluster (equation 1b), confirms that the probability that the mean rent or value premium is negative for this sample of buildings is miniscule. ${ }^{12}$ Analysis of the sets of estimated premiums also confirms that a substantial fraction of the individual premiums are indeed significantly different from the mean premium. ${ }^{13}$

\footnotetext{
${ }^{12}$ For rents, the probability is 0.0007 . For effective rents, it is 0.0000 , and for selling prices the probability that the mean value premium for green buildings is smaller than zero is 0.0000 .

${ }^{13}$ For rent, 52 percent of the estimated increments are significantly different from 0.028 , for effective rent, 45 percent of the estimated increments are significantly different from 0.064 , and for transaction values, 38 percent of the estimated increments are significantly different from 0.167 .
} 
The rent premium associated with the label on any building represents the joint effects of the energy efficiency of the building together with other unmeasured, but presumably important, attributes of the building. The fact that the estimated premiums are different from each other suggests that systematic variations in the thermal properties of buildings - even among certified green buildings - may be reflected in economic performance.

For 122 of the 199 transacted buildings that were certified as energy efficient by the Energy Star program, we obtained detailed data on energy efficiency as reported in the application for certification in the program. More specifically, we have the underlying raw data on energy use as submitted by building owners (and verified by a professional engineer) on the Statement of Energy Performance (SEP) required by the EPA for certification.

Energy Star certification is awarded to buildings which are in the top quarter of comparable buildings in terms of source energy efficiency. The source energy use of a building incorporates all transmission, delivery, and production losses for both primary and secondary energy used in the building. This measurement, in British Thermal Units (BTUs) per square foot, facilitates a more complete comparison of the gross energy used by different buildings. ${ }^{14}$

In contrast, the site energy use of a building is the amount of heat and electricity consumed by a building as reflected in utility bills, also measured in BTUs per square foot. This represents the most salient cost of energy use for building owners and occupiers. The site energy use may include a combination of purchases of primary energy (e.g., fuel oil) and secondary forms of energy (e.g., heat from a district steam system).

The SEP certification provides both measures of energy use.

\footnotetext{
${ }^{14}$ For details, see Energy Star (2008).
} 
To account for the influence of climatic conditions on energy use, we standardize the energy consumption of each Energy-Star-rated building by the total number of degree days in the CBSA in which it is located. ${ }^{15}$ Presumably, more energy is needed for the heating of buildings in metropolitan areas with more heating degree days, and more energy is needed for the cooling of buildings in cities with more cooling degree days.

In this part of the analysis, we seek to distinguish the effects of the energy-saving aspect of the rating from the intangible effects of the label itself. These latter effects may arise from the reputational or marketing benefits of the labeled building or from other unmeasured aspects of quality in rated buildings.

Our statistical models utilize data on the thermal properties of the subsample of rated buildings and the climate conditions of the clusters in which they are located. The most straightforward of these takes the form:

$$
\hat{\delta}_{n}=\alpha+\Theta_{j} \mathbf{Z}_{j n}+\eta_{n}^{*}
$$

The dependent variable $\hat{\delta}_{n}$ is the estimate from equation (1b) of the increment to market value commanded by the green building in cluster $n$, relative to the control buildings in that cluster, holding constant the hedonic characteristics of the buildings. $\mathbf{Z}_{j n}$ measures the thermal and climatic attributes $j$ of the green building in cluster $n$. As before, the Greek letters $\alpha$ and $\boldsymbol{\Theta}_{j}$ denote estimated coefficients, and $\eta_{\eta}^{*}$ is an error term. Note that the dependent variable is the regression coefficient obtained from equation (1b), estimated with error. Thus equation (2a) is

\footnotetext{
${ }^{15}$ For each day with an average temperature higher than 65 degrees, the cooling day is the difference between that average temperature and 65 degrees. Alternatively, for each day with an average temperature lower than 65 degrees, the heating day is the difference between that average temperature and 65 degrees. Data are available by CBSA from the National Climatic Data Center (www.ncdc.noaa.gov).
} 
appropriately estimated by generalized least-squares, incorporating the variance-covariance matrix of the parameters estimated in equation (1b). See Eric A. Hanushek (1974).

As an alternative, we also report estimates of the following form:

$$
\hat{\varepsilon}_{i n}^{*}=\alpha+\Theta_{j} \mathbf{Z}_{j n}+\eta_{i n}^{* *}
$$

In this formulation the dependent variable, $\hat{\varepsilon}_{i n}^{*}$, is the residual from equation (1a). It is the increment to market value commanded by the specific green building $i$ that is not attributable to its hedonic characteristics, or to the average premium estimated for a green building, or to its location in a specific cluster. Presumably, this increment reflects the energy efficiency of the specific building as well as random error.

Finally, we report estimates of the following form:

$$
\log R_{i n}-\hat{\gamma}_{n}=\alpha+\beta \mathbf{X}_{i}+\Theta_{j} \mathbf{Z}_{j n}+\eta_{i n}^{* * *}
$$

In this formulation, we rely upon the location-specific increment to value estimated for each cluster in equation (1a), $\hat{\gamma}_{n}$, using the entire sample of green buildings and control buildings. The dependent variable is the natural logarithm of value commanded by green building $i$ in cluster $n$ minus the value increment for other buildings in cluster $n$ as estimated in equation (1a).

Table 4 presents estimates of models explaining the variation in the increment in market values as a function of the energy consumption of an office building. We estimate models (2a), (2b), and (2c) in several variants. We measure energy usage in thousands of BTUs per square foot of gross space per degree day, and we distinguish between BTU usage per cooling degree day and BTU usage per heating degree day, reflecting the operation of air conditioning and heating systems. 
Panel A reports the increment to market value associated with variations in source energy usage, i.e., the total energy consumed in heating and cooling the building. Panel B reports analogous results for site energy use, i.e., the energy usage reflected in utility bills.

\section{Table 4 \\ Regression Results \\ Increment in Market Value for More Energy Efficient Buildings \\ Using Source and Site Energy}

\begin{tabular}{|c|c|c|c|c|c|c|}
\hline \multirow{2}{*}{$\begin{array}{l}\text { Panel A. Source Energy } \\
\text { Consumption } \\
\text { Per Degree Day }\end{array}$} & \multicolumn{2}{|c|}{ Model 2a } & \multicolumn{2}{|c|}{ Model 2b } & \multicolumn{2}{|c|}{ Model 2c } \\
\hline & $\begin{array}{l}-5.091 \\
{[1.679]^{* * *}}\end{array}$ & & $\begin{array}{l}-4.345 \\
{[1.360]^{* * *}}\end{array}$ & & $\begin{array}{l}-3.081 \\
{[1.564]^{*}}\end{array}$ & \\
\hline Per Degree Day (cooling) & & $\begin{array}{l}-0.218 \\
{[0.105]^{* *}}\end{array}$ & & $\begin{array}{l}-0.194 \\
{[0.085]^{* *}}\end{array}$ & & $\begin{array}{l}-0.240 \\
{[0.106]^{* *}}\end{array}$ \\
\hline Per Degree Day (heating) & & $\begin{array}{l}-1.766 \\
{[0.581]^{* * *}}\end{array}$ & & $\begin{array}{l}-1.447 \\
{[0.654]^{* *}}\end{array}$ & & $\begin{array}{l}-1.116 \\
{[0.659]^{*}}\end{array}$ \\
\hline Constant & $\begin{array}{l}0.424 \\
{[0.098]^{* * *}}\end{array}$ & $\begin{array}{l}0.405 \\
{[0.087]^{* * *}}\end{array}$ & $\begin{array}{l}0.359 \\
{[0.088]^{* * *}}\end{array}$ & $\begin{array}{l}0.333 \\
{[0.091]^{* * *}}\end{array}$ & $\begin{array}{l}5.738 \\
{[0.287]^{* * *}}\end{array}$ & $\begin{array}{l}5.687 \\
{[0.243]^{* * *}}\end{array}$ \\
\hline Sample Size & 122 & 122 & 122 & 122 & 122 & 122 \\
\hline $\mathrm{R}^{2}$ & 0.07 & 0.08 & 0.08 & 0.08 & 0.32 & 0.34 \\
\hline Adj $R^{2}$ & 0.06 & 0.07 & 0.07 & 0.06 & 0.21 & 0.23 \\
\hline \multicolumn{7}{|l|}{$\begin{array}{l}\text { Panel B. Site Energy } \\
\text { Consumption }\end{array}$} \\
\hline Per Degree Day & $\begin{array}{l}-11.039 \\
{[4.894]^{* *}}\end{array}$ & & $\begin{array}{l}-9.805 \\
{[3.922]^{* *}}\end{array}$ & & $\begin{array}{l}-5.712 \\
{[4.465]}\end{array}$ & \\
\hline Per Degree Day (cooling) & & $\begin{array}{l}-0.544 \\
{[0.304]^{*}}\end{array}$ & & $\begin{array}{l}-0.442 \\
{[0.247]^{*}}\end{array}$ & & $\begin{array}{l}-0.551 \\
{[0.317]^{*}}\end{array}$ \\
\hline Per Degree Day (heating) & & $\begin{array}{l}-5.280 \\
{[1.917]^{* * *}}\end{array}$ & & $\begin{array}{l}-4.189 \\
{[1.952]^{* *}}\end{array}$ & & $\begin{array}{l}-2.938 \\
{[1.941]}\end{array}$ \\
\hline Constant & $\begin{array}{l}0.350 \\
{[0.096]^{* * *}}\end{array}$ & $\begin{array}{l}0.387 \\
{[0.089]^{* * *}}\end{array}$ & $\begin{array}{l}0.302 \\
{[0.086]^{* * *}}\end{array}$ & $\begin{array}{l}0.309 \\
{[0.090]^{* * *}}\end{array}$ & $\begin{array}{l}5.600 \\
{[0.299]^{* * *}}\end{array}$ & $\begin{array}{l}5.653 \\
{[0.259]^{* * *}}\end{array}$ \\
\hline Sample Size & 122 & 122 & 122 & 122 & 122 & 122 \\
\hline $\mathrm{R}^{2} \mathrm{~T}$ & 0.04 & 0.07 & 0.05 & 0.06 & 0.31 & 0.33 \\
\hline Adj $R^{2}$ & 0.03 & 0.05 & 0.04 & 0.04 & 0.20 & 0.22 \\
\hline
\end{tabular}

Notes:Energy consumption is measured in kBTUs per square foot of gross space. See:

www.energystar.gov/index.cfm?c=evaluate_performance.bus_benchmark_comm_bldgs

Standard errors are in brackets. Significance at the $0.10,0.05$, and 0.01 levels are indicated by $*, * *$, and $* * *$, respectively.

There is a clear inverse relationship between market value and energy usage - among buildings that have all been certified as energy efficient. This relationship holds for source energy use as well as site energy use. Further calculations - using the coefficients of model (2b) 
- show that a ten percent reduction in site or source energy use result in an increase in market value of 1.1 percent and 1.2 percent, respectively, over and above the average label premium of 16 percent. $^{16}$

This raises the question whether the value increment of a certified building can be attributed solely to lower energy bills, or whether intangible effects - like marketing or perceptions of staff well being - play a role as well. To analyze the effect of energy efficiency upon market values, we make comparisons between the monetary value of energy savings and the consequent increment to market values. For each rated building, the SEP reports energy use in BTUs separately for electricity and natural gas. Using the state average price of electricity and natural gas ${ }^{17}$ we estimate the monetary savings associated with a ten percent reduction in site energy use for each building. From the results in Panel A of Table 4, model (2b), and information on the heating and cooling degree days associated with each building, we can estimate the increment to value associated with this increase in thermal efficiency. The calculation implies that, on average, a dollar of energy savings yields 18.32 dollars in increased market value - implying a capitalization rate of about 5.5 percent. Alternatively, if the capitalization rate were known to be, say, six percent, ${ }^{18}$ then the other desirable attributes of a more energy-efficient building (better engineering, design, etc.) would contribute about eight percent to the increased valuation. An analogous calculation using source energy suggests that a

\footnotetext{
${ }^{16}$ This calculation is based on the average site (source) energy use, which is 66 (197) kBTU per sq. ft., with a standard deviation of 17 (44) kBTUs per sq. ft., the average number of heating degree days, which is 3,166 per annum and the average number of cooling degree days, which is 1,292 per annum.

${ }_{18}^{17}$ Data available from the Energy Information Administration (www.eia.doe.gov).

18 The volatility of historic series of rental cash flows is comparable to the volatility of commercial gas and electricity prices. We can therefore approximate the discount rate for energy savings by the U.S. national average of the capitalization rate for commercial office buildings. Based on data provided by CBRE Torto Wheaton Research, the transaction-weighted capitalization rate for the ten largest U.S. cities is estimated to be 6.1 percent in October 2007.
} 
dollar of source energy savings yields an increment of 20.73 dollars in increased market value, a value higher by 13 percent. These results may suggest that the value premium for green buildings is more than an intangible labeling effect. ${ }^{19}$

If lower energy bills were the only signal provided by the rating of a building, then we would not expect to find much difference in the way firms from different industries would use green space relative to conventional office space. For example, there would be no apparent reason for an oil and gas company to use relatively more green office space in a given cluster than for a food retailer. ${ }^{20}$ But a more detailed investigation of the tenancy and occupancy of these buildings reveals significant differences in the degree to which firms from different industries rent green space (Piet M. A. Eichholtz, Nils Kok, and John M. Quigley, 2009). Ceteris paribus, firms active in the refining and energy sector are more likely to rent green space than conventional office space in the same cluster, despite the higher expense. Other relatively heavy users of green office space are in the finance, insurance and real estate sector and in public administration, while manufacturing, retail, and wholesale trade are underrepresented in green office buildings. These cross-industry differences suggest that intangibles, which may differ with the nature of firms and industries, play a role in determining the economic premium for green buildings.

The data at hand cannot provide a conclusive answer to the question whether the value increments of green office space are attributable only to savings on energy costs, or whether intangibles also play a role. However, the empirical evidence (e.g., the capitalization rate required

\footnotetext{
${ }^{19}$ But, of course, the estimated increment to value varies among these buildings, and we cannot reject the hypothesis that the mean increment for site energy is 16.67 dollars (i.e., full capitalization at 6 percent) rather than the point estimate of 18.32 dollars or that the mean source energy increment is 18.32 dollars (i.e., the same as that estimated for site energy) rather than the point estimate of 20.73 dollars.

${ }^{20}$ This relies upon the assumption that energy needs for commercial office space are similar across industries.
} 
and the fact that we find value effects beyond the direct energy cost savings) provides at least a hint that intangibles do play a role, beyond the direct effects of savings on firms' energy bills.

\section{Conclusions}

This paper reports the only systematic evidence on the economic value of certification of green buildings to the U.S. economy. In contrast to the anecdotal evidence on the economic effects of investments in environmentally sustainable buildings, the research reported here is based upon impersonal market comparisons.

For each commercial building in the country which has obtained a LEED and or Energy Star label, we identified a control group consisting of all commercial properties located within about 1,300 feet. For this sample - about 10,000 buildings divided into about 900 clusters, each containing one labeled building and nearby unlabeled buildings - we relate market rents or selling prices of the properties to the hedonic characteristics of properties, within very small geographical areas of about 0.2 square miles.

The results clearly indicate the importance of a green label in affecting the market rents and values of commercial space. The results suggest that an otherwise identical commercial building with an Energy-Star certification will rent for about three percent more per square foot; the difference in effective rent is estimated to be about six percent. The increment to the selling price may be as much as 16 percent.

These effects are large, and they are consistent. As noted above, at prevailing capitalization rates of six percent, the increment to effective rents (estimated in Table 2) implies that the value of a green building is about $\$ 5.5$ million more than the value of a comparable unrated building nearby. From Table 3, the incremental value of a green building is estimated to be about $\$ 5.7$ million more than that of a comparable unrated building nearby. 
The premium in rents and values associated with an energy label varies considerably across buildings and locations. The premium is negatively related to the location premium for a building, within and between cities: a label appears to add more value in smaller markets and regions and in the more peripheral parts of larger metropolitan areas, where location rents are lower. We disentangle the energy savings required to obtain a label from the unobserved effects of the label itself, which could serve as a measure of reputation and marketing gains obtained from occupying a green building. The energy savings per se are important. A ten percent decrease in energy consumption leads to an increase in value of about one percent, over and above the rent and value premium for a labeled building. However, the intangible effects of the label itself - beliefs about worker productivity or improved corporate image, for example - also seem to play a role in determining the value of green buildings in the marketplace. Not all of a building's energy use measured by the Energy Star label is directly linked to the ultimate energy bill, yet even reducing that energy consumption yields positive effects on a building's value.

Finally, these results provide evidence on the importance of publicly provided information in affecting the choices of private firms about energy use. The energy efficiency of capital inputs can be signaled to the owners and tenants of buildings very cheaply, ${ }^{21}$ and the evidence suggests that the private market does incorporate this information in the determination of rents and asset prices. Even if the external effects of energy efficiency were very small, this information program would seem to be a sensible use of public resources.

\footnotetext{
${ }^{21}$ Public expenditures on the Energy Star program for commercial buildings are quite small, and the program employs less than two dozen civil servants (http://www.cfo.doe.gov/08budget).
} 


\section{References}

Baron, David. 2001. "Private Politics, Corporate Social Responsibility, and Integrated Strategy." Journal of Economics \& Management Strategy, 10(1): 7-45.

Bollinger, Christopher R., Keith R. Ihlanfeldt, and David. R. Bowes. 1998. "Spatial Variation in Office Rents within the Atlanta Region." Urban Studies, 35(7): 1097-118.

Black, Dan A., and Jeffrey Smith. 2004. "How Robust is the Evidence on the Effects of College Quality? Evidence from Matching." Journal of Econometrics, 121: 99-124.

California's Sustainable Building Task Force. 2003. The Costs and Financial Benefits of Green Buildings. Sacramento, California.

Eichholtz, Piet M. A., Nils Kok, and John M. Quigley. 2009. "Why Do Companies Rent Green? Real Property and Corporate Social Responsibility." University of California, Berkeley Program on Housing and Urban Policy Working Paper W09-004.

Energy Star. 2008. U.S. Environmental Protection Agency. www.energystar.gov/index.cfm?c=evaluate_performance.bus_benchmark_comm_bldgs.

Frombrun, Charles J., and Mark Shanley. 1990. "What's in a Name? Reputation Building and Corporate Strategy." The Academy of Management Journal, 33(2): 233-58.

Glasscock, John L., Shirin Jahanian, and C. F. Sirmans. 1990. "An Analysis of Office Market Rents." AREUEA Journal, 18: 105-19.

Gunnelin, Åke, and Bo Söderberg. 2003. "Term Structures in the Office Rental Market in Stockholm." Journal of Real Estate Finance and Economics, 26(2-3): 241-65.

Hanushek, Eric A. 1974. "Efficient Estimators for Regressing Regression Coefficients." American Statistician, 28(2): 66-67. 
Klein, Benjamin, and Keith B. Leffler. 1981. "The Role of Market Forces in Assuring Contractual Performance." The Journal of Political Economy, 89(4): 615-41.

Lyon, Thomas P., and John W. Maxwell. 2006. "Greenwash: Corporate Environmental Disclosure under Threat of Audit." University of Michigan, Ross School of Business, Working Paper 1055.

Margolis, Joshua D., and James P. Walsh. 2003. "Misery Loves Company: Rethinking Social Initiatives by Business." Administrative Science Quarterly, 48(2): 268-305.

Maxwell, John W., Thomas P. Lyon, and Steven C. Hackett. 2000. "Self-Regulation and Social Welfare: The Political Economy of Corporate Environmentalism." Journal of Law and Economics, 43(2): 583-617.

Milgrom, Paul R., and John Roberts. 1986. "Price and Advertising Signals of Product Quality." Journal of Political Economy, 94(4): 796-821.

Orlitzky, Mark and Benjamin, John D. 2001. "Corporate Social Performance and Firm Risk: A Meta-Analytic Review." Business and Society, 40(4): 369-96.

Öven, V. Attila, and Dilek Pekdemir. 2006. "Office Rent Determinants Utilising Factor Analysis - a Case Study for Istanbul." Journal of Real Estate Finance and Economics, 33(1): 51-73.

Quigley, John M. 1991. "Market Induced and Government Mandated Energy Conservation in the Housing Market: Econometric Evidence from the U.S." Review of Urban and Regional Development Studies, 3(1): 28-38.

RICS. 2005. Green Value. London and Vancouver: Royal Institute of Chartered Surveyors.

Rosen, Kenneth T. 1984. "Toward a Model of the Office Building Sector." AREUEA Journal, 12: $261-69$. 
Rosenbaum, Paul R., and Donald B. Rubin. 1983. "The Central Role of the Propensity Score in Observational Studies for Causal Effects." Biometrika, 70(1): 41-55.

Sivitanidou, Rena. 1995. "Urban Spatial Variations in Office-Commercial Rents." Journal of Urban Economics, 38(1): 23-49.

Social Investment Forum. 2007. 2007 Report on Socially Responsible Investing Trends in the United States, Washington, D.C.

Turban, Daniel B., and Daniel W. Greening. 1997. "Corporate Social Performance and Organizational Attractiveness to Prospective Employees." Academy of Management Journal, 40(3): 658-72.

US EPA Indoor Air Quality. 2009. U.S. Environmental Protection Agency. www.epa.gov/iaq.

Waddock, Sandra A., and Samuel B. Graves. 1997. "The Corporate Social PerformanceFinancial Performance Link." Strategic Management Journal, 18(4): 303-19.

Webb, R. Brian, and Jeffrey D. Fisher. 1996. "Development of an Effective Rent Index for the Chicago CBD." Journal of Urban Economics, 39: 1-19.

Wheaton, William C., and Raymond Torto. 1994. "Office Rent Indices and Their Behavior over Time." Journal of Urban Economics, 35: 121-39.

White, Halbert. 1980. "A Heteroskedasticity-Consistent Covariance Matrix Estimator and a Direct Test for Heteroskedasticity." Econometrica, 48(4): 817-38. 